\title{
Biochemical genetics of blackfly isozymes \\ II. Genetic variability and differentiation among natural populations of Simulium ochraceum, the vector of onchocerciasis, in Guatemala ${ }^{1)}$
}

\author{
Takeshi Agatsuma, ${ }^{2)}$ Kiichi Uemoto") and J. Onofre Ochoa A." \\ 2) Department of Parasitology, Kochi Medical School, Oko-cho, Nankoku, Kochi 781-51, Japan \\ ${ }^{3)}$ Department of Medical Zoology, Kyoto Prefectural University of Medicine, \\ Kawaramachi Hirokoji, Kyoto 602, Japan \\ 4) Laboratorio de Investigación Cientifica para Control de la Oncocercosis, \\ SNEM, 5a Ave. 11-40, Zona 11, Guatemala, Guatemala C.A.
}

(Received: March 29, 1986)

Key words: blackflies, enzyme electrophoresis, isozymes, biochemical population genetics, onchocerciasis, Guatemala.

\begin{abstract}
Electrophoretic studies of isozymes in Simulium ochraceum, the main vector of Central American onchocerciasis, were performed using starch gel electrophoresis. A total of six larval and adult populations originating from four localities in Guatemala (a non-endemic area, Finca La Ruda; a low-endemic area, Finca Rincon; and two high-endemic areas, Finca Brote and Finca Recreo) were analyzed electrophoretically. The enzymes examined were adenylate kinase (AK), alkaline phosphatase (ALP), glucose phosphate isomerase (GPI), hexokinase (HK), isocitrate dehydrogenase (IDH), leucine aminopeptidase (LAP), malic enzyme (ME), and phosphoglucomutase (PGM). Of the eight, six enzymes, AK, ALP, $\mathrm{HK}, \mathrm{IDH}, \mathrm{LAP}$, and ME showed no variation either within or among populations. The other two, GPI and PGM, were found to be highly polymorphic in all six populations. The $\chi^{2}$ test for fit to Hardy-Weinberg equilibrium (HWE) revealed the distribution for the phenotypes of the two polymorphic enzymes not to be significantly out of the HWE. Averages of values of proportion of polymorphic loci $(P)$ and heterozygosity per individual $(H)$ of the six populations were 0.234 and 0.084 , respectively, each of which was almost the same value as that for different groups of organisms. Genetic diversity among populations was measured by $F_{\mathrm{ST}}$ and $G_{\mathrm{ST}}$, both of which showed that the non-endemic population from Finca La Ruda (D1) was greatly differentiated genetically from the other five populations. The estimates of genetic distance also showed that the D1 population was very distant from the other populations.
\end{abstract}

1) This study was supported by the Ministry of Public Health, Guatemala and Japan International Cooperation Agency (JICA).

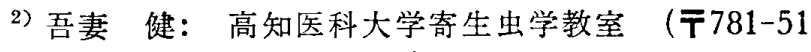
高知県南国市岡豊町小蓮)

3) 上本騏一：京都府立医科大学医動物学教室（甬602

宗都市上京区河原町広小路) 


\section{INTRODUGTION}

Simulium ochraceum is a main vector of human onchocerciasis in Guatemala and Mexico. Recently, Hirai (1985) carried out a chromosome study and found marked differences in chromosomal banding patterns among populations from remote areas including several endemic areas of onchocerciasis in the two countries. Hirai concluded that there are at least three sibling species in the $S$. ochraceum complex. This finding accorded with the species complex theory of $S$. ochraceum proposed by Uemoto (1984) who had studied this "species" from a morphological point of view. To evaluate their findings in another manner, isozyme studies were performed here on two sibling species out of the three which they proposed.

Isozymes are genetically determined variants and will serve as a useful tool in detecting geographic variations, as in the determination of vector populations (Taylor and Muller, 1979). At present, there are relatively few reports on Simulium isozymes (May et al., 1977; Townson and Meredith, 1979; Meredith and Townson, 1981; Meredith, 1982; Snyder and Linton, 1984). We have already done comparative studies on the isozymes of three species ( $S$. ochraceum, $S$. metallicum and $S$. horacioi) in Guatemala, and found that all three could be clearly distinguished from each other by the isozyme patterns (Agatsuma et al., 1986). In this report, we will present isozyme analyses of six populations of $S$. ochraceum responsible for onchocerciasis transmission in Guatemala from a standpoint of biochemical population genetics.

\section{Materials and Methods}

We examined eight enzymes controlling ten separate loci using starch gel electrophoresis: adenylate kinase (AK:EG 2.7.4.3), alkaline phosphatase (ALP:EG 3.1.3.1), glucosephosphate isomerase (GPI:EG 5.3.1.9), hexokinase (HK:EG 2.7.1.1), isocitrate dehydrogenase (IDH:EG 1.1.1.42), leucine aminopeptidase (LAP:EC 3.4.1.1), malic enzyme (ME: EG 1.1.1.40), and phosphoglucomutase (PGM:EC 2.7.5.1).

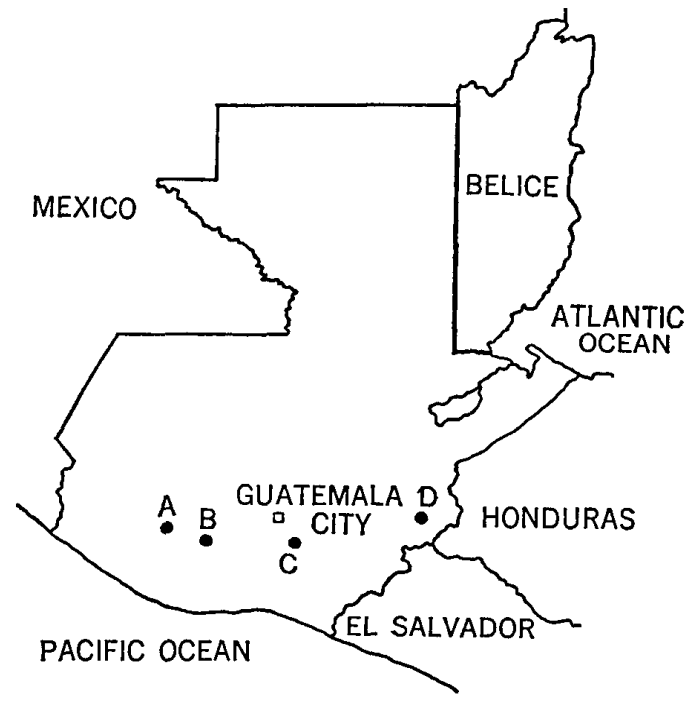

Fig. 1 Map of Guatemala showing the areas of Finca Brote (A), Finca Recreo (B), Finca Rincon (C), and Finca La Ruda (D).

Four remote localities, Finca Brote (A), Finca Recreo (B), Finca Rincon (C) and Finca La Ruda (D), were selected for sampling of adults and/or larvae. These regions are situated across southern Guatemala from west to east (Fig. 1), and collections of blackflies were made in the same sites as those sampled in the chromosomal study of Hirai (1985). The former three localities are known to be endemic area of onchocerciasis, while the latter is a non-endemic area (Table 1). Both adults and larvae were collected in two localities, Finca Recreo and Rincon, but only adult flies were caught in Finca Brote. In the fourth locality, Finca La Ruda, adults and pupae were difficult to find, probably because of low population densities and little anthropophilism of the blackflies inhabiting this region (Ito, personal communication). Consequently, only larvae were examined for this locality. The number of individuals examined for each enzyme and population is given in Table 7 (in this study, larval populations were regarded as a separate population).

Electrophoretic procedures, buffer systems and staining methods for each enzyme other than IDH and ME were the same as those of Agatsuma et al. (1986). Electrophoretic condition and staining mixtures for IDH and ME are shown in Table 2. For the larval materials from Finca Rincon, five enzymes, 
Table 1 Collection sites and the analyzed number of individuals in six blackfly populations sampled from four localities in Guatemala.

\begin{tabular}{|c|c|c|c|c|c|c|c|c|c|c|c|}
\hline & \multirow{2}{*}{ Localities } & \multirow{2}{*}{ Populations } & \multirow{2}{*}{$\begin{array}{l}\text { Endemicity of } \\
\text { onchocerciasis }\end{array}$} & \multicolumn{8}{|c|}{ Enzymes* } \\
\hline & & & & $\mathrm{AK}$ & ALP & GPI & HK & $\mathrm{IDH}$ & LAP & ME & PGM \\
\hline A. & Finca Brote & A 1 (adults) & high & 30 & 30 & 28 & 30 & 20 & —** & 20 & 27 \\
\hline \multirow[t]{2}{*}{ B. } & Finca Recreo & B 1 (adults) & \multirow{2}{*}{ high } & 30 & 30 & 27 & 30 & 20 & - & 20 & 28 \\
\hline & & B 2 (larvae) & & 30 & 30 & 30 & 30 & 20 & 30 & 20 & 29 \\
\hline \multirow[t]{2}{*}{ C. } & Finca Rincon & C 1 (adults) & \multirow{2}{*}{ low } & 30 & 40 & 30 & 30 & 20 & - & 20 & 30 \\
\hline & & C2 (larvae) & & 30 & 40 & 29 & 30 & 20 & 40 & 20 & $30 * * *$ \\
\hline D. & Finca La Ruda & D1 (larvae) & null & 60 & 40 & 40 & 60 & 20 & 40 & 20 & 40 \\
\hline
\end{tabular}

* For abbreviation see text. ** LAP reveals no activity in adult stage. *** The PGM data of larval population from this locality have been described (Agatsuma et al., 1986).

Table 2 Electrophoretic condition and staining mixtures for two enzymes, isocitrate dehydrogenase (IDH) and malic enzyme (ME).

Electrophoretic condition

\begin{tabular}{|c|c|c|c|c|c|}
\hline \multicolumn{2}{|c|}{$\begin{array}{l}\text { Electrode buffer: } \\
\text { Gel buffer: } \\
\text { Condition: }\end{array}$} & \multicolumn{4}{|c|}{$\begin{array}{l}0.155 \mathrm{~m} \text { Tris, } 0.043 \mathrm{~m} \text { Citrate } \\
\text { Dilute } 66.7 \mathrm{ml} \text { of electrode buffer to } 11 \\
30 \mathrm{~mA} \text { constant current } 4 \mathrm{hr}\end{array}$} \\
\hline \multicolumn{6}{|c|}{ Staining mixtures } \\
\hline Enzymes & \multicolumn{2}{|c|}{ Substrates } & Coenzymes & \multicolumn{2}{|c|}{ Other additions } \\
\hline \multirow[t]{4}{*}{$\mathrm{IDH}$} & \multirow{4}{*}{\multicolumn{2}{|c|}{$\begin{array}{l}\mathrm{Na}_{3} \text { isocitrate } \\
20 \mathrm{mg}\end{array}$}} & NADP & MTT & PMS \\
\hline & & & $2 \mathrm{mg}$ & $2 \mathrm{mg}$ & $2 \mathrm{mg}$ \\
\hline & & & & $\mathrm{MnCl}_{2}$ & $\begin{array}{l}\text { Tris buffer } \\
(\mathrm{pH} 8.0)\end{array}$ \\
\hline & & & & $2 \mathrm{mg}$ & $20 \mathrm{ml}$ \\
\hline \multirow[t]{4}{*}{$\mathrm{ME}$} & \multicolumn{2}{|c|}{ Malate } & NADP & MTT & PMS \\
\hline & \multirow[t]{3}{*}{$20 \mathrm{~m}$} & & $2 \mathrm{mg}$ & $2 \mathrm{mg}$ & $2 \mathrm{mg}$ \\
\hline & & & & $\mathrm{MgCl}_{2}$ & $\begin{array}{l}\text { Tris buffer } \\
(\mathrm{pH} 8.0)\end{array}$ \\
\hline & & & & $2 \mathrm{mg}$ & $20 \mathrm{ml}$ \\
\hline
\end{tabular}

AK, ALP, GPI, HK and LAP, were reexamined in this study (see Agatsuma et al., 1986).

The genetic variability within a population was quantified by measuring the proportion of polymorphic loci and average heterozygosity per individual $(H)$. A polymorphic locus was defined as one in which the frequency of the most common allele was less than 0.99 . The average heterozygosity was calculated as $\vec{H}=1-\overline{\sum q_{i}{ }^{2}}$, where $q_{i}$ is the frequency of the $i$-th allele at a locus, and the average was taken of all the loci examined. Amount of genetic differentiation among local populations was evaluated by $F_{\mathrm{ST}}$ and $G_{\mathrm{ST}}$ (Nei, $1975) . \quad F_{\mathrm{ST}}$ was calculated for each polymorphic locus by using the following formula: $F_{\mathrm{ST}}=\left(\sigma_{q}^{2}-{\overline{\sigma_{\delta q}}}^{2}\right) / \bar{q}(1-\bar{q})$, where $\bar{q}$ and $\sigma_{q}{ }^{2}$ were mean and variance, respectively, of frequencies $(q)$ of the most common allele and $\overline{\sigma_{\delta q}{ }^{2}}$, the average sampling variance in estimation of $q$, that is, ${\overline{\sigma_{\delta q}}}^{2}=\bar{q}(1-$ $\bar{q}) / 2 \bar{n}$, in which $\bar{n}$ was harmonic mean of the number of blackflies examined in the six populations. Arithmetic mean $\left(\overline{F_{\mathrm{ST}}}\right)$ of $F_{\mathrm{ST}}$ at two polymorphic loci was used for evalua- 
tion of genetic differentiation between the populations which was also quantified by estimating the coefficient of gene differentiation, $G_{\mathrm{ST}}$. The magnitude of genetic differentiation between different local populations within a large population can be measured by the relative proportion of gene diversity between the local populations to that in the total population. The gene diversity of the total population $\left(H_{\mathrm{T}}\right)$ and that of the local populations $\left(H_{\mathrm{S}}\right)$, which was an average of heterozygosity among local populations were defined as follows: $H_{\mathrm{T}}=1-\sum_{k}\left(\sum_{i} q_{i k}\right)^{2} / S^{2} ; \quad H_{S}=1-$ $\sum_{i} \sum_{k} q_{i k}{ }^{2} / S$, where $q_{i k}$ was the gene frequency of the $k$-th allele in the $i$-th local population and $S$ was the number of local populations in the total population. When a number of loci are examined, the average gene diversity can be calculated by taking the average of all of the loci examined. Average gene diversity between local populations $\left(D_{\mathrm{ST}}\right)$ is defined as $D_{\mathrm{ST}}=H_{\mathrm{T}}-H_{\mathrm{S}} . \quad G_{\mathrm{ST}}$, a measure of genetic differentiation, is defined as $G_{\mathrm{ST}}=D_{\mathrm{ST}} / H_{\mathrm{T}}$.

For the consideration of relative phylogenetic relationship among local populations, the normalized identity of genes $(I)$ and the standard genetic distance or average net codon difference $(D)$ (Nei, 1972) were used.

\section{Results}

\section{Description of enzyme variants}

Of the eight enzymes tested, GPI and PGM showed high polymorphism in most of the populations examined (Fig. 2). The remaining six enzymes, AK, ALP, IDH, HK, LAP and $M E$ showed no variation either within or between populations. Electrophoretic patterns of four of the six enzymes (AK, ALP, HK and LAP) have previously been described (Agatsuma et al., 1986). The patterns of IDH and ME are shown in Fig. 2; that is, in both enzymes, one distinct band was observed without any varitaion within or between populations. Detailed interpretation of the enzyme variations are as follows:

Glucosephosphate isomerase (GPI). We found five genotypes and were able to identify four alleles (Table 3 ). Allele $l$ was the most common in all of six populations examined, and allele 3 was extremely low in its frequency, being found only in a larval population in Finca Rincon (C2). The Finca La Ruda population (D1) showed a low level of heterogeneity $(H=0.049)$, while the other populations were rather heterogeneous $(H>0.187)$ as shown in Table 4.

Phosphoglucomutase (PGM). A remarkably high polymorphism was observed in every population. Ten different genotypes and seven alleles were found (Table 5).

Table 3 The presumptive genotype frequencies observed at GPI locus in six populations of Simulium ochraceum sampled from four different localities in Guatemala.

\begin{tabular}{ccccccc}
\hline & \multicolumn{7}{c}{ Genotypes } \\
\cline { 2 - 7 } Populations & $1-1$ & $1-2$ & $2-2$ & $1-3$ & $1-4$ & Total \\
\hline A1 & 18 & 7 & 0 & 0 & 3 & 28 \\
B1 & 20 & 5 & 1 & 0 & 1 & 27 \\
B2 & 24 & 4 & 0 & 0 & 2 & 30 \\
C1 & 21 & 5 & 2 & 0 & 2 & 30 \\
C2 & 16 & 7 & 0 & 2 & 4 & 29 \\
D1 & 38 & 0 & 0 & 0 & 2 & 40 \\
\hline
\end{tabular}
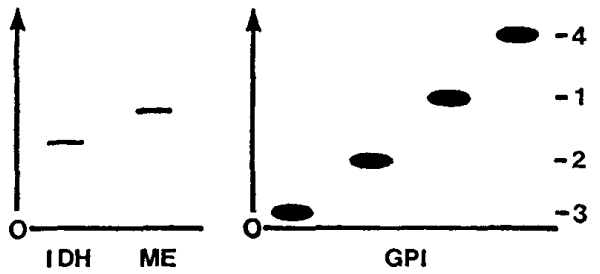

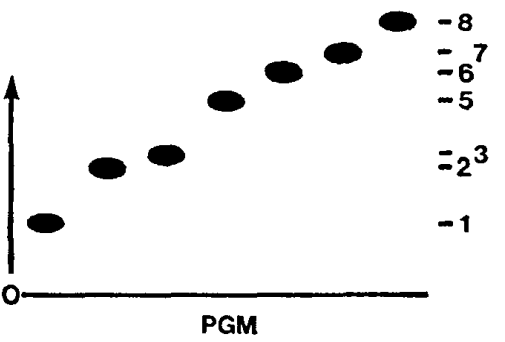

Fig. 2 Electrophoretic zymograms of two enzymes, IDH and ME, and diagrammatic representation of alleles of two enzymes, GPI and PGM, in S. ochraceum.

The number shows alleles detected in the natural populations of S. ochraceum in Guatemala. See Tables 4 and 6 . 
Table 4 Allele frequencies at GPI locus estimated on the basis of the genotype frequencies shown in Table 3 .

\begin{tabular}{cccccc} 
& \multicolumn{5}{c}{ Alleles } \\
\cline { 2 - 6 } Populations & 1 & 2 & 3 & 4 & $H^{*}$ \\
\hline A1 & 0.821 & 0.125 & 0.000 & 0.054 & 0.307 \\
B1 & 0.852 & 0.129 & 0.000 & 0.019 & 0.257 \\
B2 & 0.900 & 0.067 & 0.000 & 0.033 & 0.187 \\
C1 & 0.817 & 0.150 & 0.000 & 0.033 & 0.309 \\
C2 & 0.776 & 0.121 & 0.034 & 0.069 & 0.378 \\
D1 & 0.975 & 0.000 & 0.000 & 0.025 & 0.049 \\
\hline
\end{tabular}

* $H=1-\sum q_{i}{ }^{2}$.

Allele 5 was the most common in all populations, and there was little difference among the frequencies of this allele except for the D1 population (Table 6 ).

\section{Hardy-Weinberg equilibrium}

As a test of the genetic hypothesis for each locus, electrophoretic patterns were examined for their goodness-of-fit to the Hardy-Weinberg equilibrium (HWE) model. Because of the small number of observed individuals, genotypes were grouped as if they were produced by a pair of alleles. $\chi^{2}$ tests revealed that the distribution for the phenotypes of two polymorphic enzymes, GPI and PGM, did not differ significantly from the HWE, as shown in Table 7.

\section{Genetic variability within populations}

Average of $P$ values of six populations was 0.243 with a range of $0.200-0.286$ (Table 8 ) which was similar to that of $P$ values found for different groups of organisms (about 0.300 ) (Nei, 1975). On the other hand, $\vec{H}$ ranged from 0.028 to 0.113 with a mean of 0.084 , and the lowest value of $\bar{H}$ was obtained from the D1 population in a non-

Table 5 The presumptive genotype frequencies at $P G M$ locus in 6 populations of $S$. ochraceum from 4 localities in Guatemala.

\begin{tabular}{|c|c|c|c|c|c|c|c|c|c|c|c|}
\hline \multirow{2}{*}{ Populations } & \multicolumn{10}{|c|}{ Genotypes } & \multirow{2}{*}{$\frac{H^{* *}}{\text { Total }}$} \\
\hline & $1-1$ & $1-5$ & $1-6$ & $2-5$ & $3-5$ & $5-5$ & $5-6$ & $5-7$ & $5-8$ & $6-6$ & \\
\hline $\mathrm{A} 1$ & 2 & 4 & 2 & 0 & 1 & 14 & 4 & 0 & 0 & 0 & 27 \\
\hline B 1 & 0 & 11 & 0 & 1 & 1 & 11 & 3 & 1 & 0 & 0 & 28 \\
\hline B 2 & 1 & 7 & 2 & 2 & 0 & 10 & 3 & 3 & 1 & 0 & 29 \\
\hline $\mathrm{C} 1$ & 0 & 7 & 0 & 0 & 2 & 17 & 1 & 2 & 0 & 1 & 30 \\
\hline $\mathrm{C} 2^{*}$ & 0 & 5 & 1 & 0 & 3 & 16 & 3 & 2 & 0 & 0 & 30 \\
\hline D 1 & 0 & 6 & 1 & 0 & 0 & 31 & 2 & 0 & 0 & 0 & 40 \\
\hline
\end{tabular}

* Agatsuma et al. (1986).

Table 6 Allele frequencies at $P G M$ locus estimated on the basis of the genotype frequencies shown in Table 5 .

\begin{tabular}{|c|c|c|c|c|c|c|c|c|}
\hline \multirow{2}{*}{ Populations } & \multicolumn{8}{|c|}{ Alleles } \\
\hline & 1 & 2 & 3 & 5 & 6 & 7 & 8 & $H^{* *}$ \\
\hline $\mathrm{A} 1$ & 0.185 & 0.000 & 0.019 & 0.685 & 0.111 & 0.000 & 0.000 & 0.484 \\
\hline B 1 & 0.196 & 0.018 & 0.018 & 0.696 & 0.054 & 0.018 & 0.000 & 0.473 \\
\hline B 2 & 0.190 & 0.034 & 0.000 & 0.621 & 0.086 & 0.052 & 0.017 & 0.567 \\
\hline $\mathrm{C} 1$ & 0.100 & 0.000 & 0.033 & 0.767 & 0.050 & 0.033 & 0.000 & 0.397 \\
\hline $\mathrm{C} 2^{*}$ & 0.100 & 0.000 & 0.050 & 0.750 & 0.067 & 0.033 & 0.000 & 0.419 \\
\hline D1 & 0.087 & 0.000 & 0.000 & 0.875 & 0.038 & 0.000 & 0.000 & 0.226 \\
\hline
\end{tabular}

* Agatsuma et al. (1986), ** $H=1-\Sigma q_{i}{ }^{2}$. 
Table 7 Statistical analyses of genotype frequencies in the 6 natural populations of Simulium ochraceum from Guatemala.

\begin{tabular}{|c|c|c|c|c|c|c|c|c|}
\hline \multirow{2}{*}{ Populations } & \multicolumn{3}{|c|}{ GPI frequencies } & \multirow{2}{*}{$\chi^{2}$} & \multicolumn{3}{|c|}{ PGM frequencies } & \multirow{2}{*}{$\chi^{2}$} \\
\hline & $1-1$ & $1-\mathbf{i}$ & $i-i^{a}$ & & $5-5$ & $5-i$ & $\mathrm{i}-\mathrm{i}^{\mathrm{a}}$ & \\
\hline A 1 & $\begin{array}{l}18 \\
(18.87)\end{array}$ & $\begin{array}{l}10 \\
(8.23)\end{array}$ & $\begin{array}{l}0 \\
(0.90)^{b}\end{array}$ & $1.321^{\mathrm{ns}}$ & $\begin{array}{l}14 \\
(12.67)\end{array}$ & $\begin{array}{c}9 \\
(11.65)\end{array}$ & $\begin{array}{l}4 \\
(2.68)\end{array}$ & $1.393^{\mathrm{ns}}$ \\
\hline B 1 & $\begin{array}{l}20 \\
(19.60)\end{array}$ & $\begin{array}{l}6 \\
(6.80)\end{array}$ & $\begin{array}{l}1 \\
(0.60)\end{array}$ & $0.369^{\mathrm{ns}}$ & $\begin{array}{l}11 \\
(13.56)\end{array}$ & $\begin{array}{l}17 \\
(11.85)\end{array}$ & $\begin{array}{l}0 \\
(2.59)\end{array}$ & 5. $311^{*}$ \\
\hline B 2 & $\begin{array}{l}24 \\
(24.30)\end{array}$ & $\begin{array}{l}6 \\
(5.40)\end{array}$ & $\begin{array}{l}0 \\
(0.30)\end{array}$ & $0.370^{\mathrm{ns}}$ & $\begin{array}{l}10 \\
(11.18)\end{array}$ & $\begin{array}{l}16 \\
(13.65)\end{array}$ & $\begin{array}{l}3 \\
(4.17)\end{array}$ & $0.857^{\mathrm{ns}}$ \\
\hline $\mathrm{C} 1$ & $\begin{array}{l}21 \\
(20.02)\end{array}$ & $\begin{array}{l}7 \\
(8.97)\end{array}$ & $\begin{array}{l}2 \\
(1.01)\end{array}$ & $1.451^{\mathrm{ns}}$ & $\begin{array}{l}17 \\
(17.65)\end{array}$ & $\begin{array}{l}12 \\
(9.94)\end{array}$ & $\begin{array}{l}1 \\
(2.41)\end{array}$ & $1.276^{\mathrm{ns}}$ \\
\hline $\mathrm{C} 2$ & $\begin{array}{l}16 \\
(17.46)\end{array}$ & $\begin{array}{c}13 \\
(10.08)\end{array}$ & $\begin{array}{c}0 \\
(1.46)\end{array}$ & $2.428^{\mathrm{ns}}$ & $\begin{array}{l}16 \\
(16.88)\end{array}$ & $\begin{array}{l}13 \\
(11.25)\end{array}$ & $\begin{array}{l}1 \\
(1.87)\end{array}$ & $0.723^{\mathrm{ns}}$ \\
\hline $\mathrm{D} 1$ & $\begin{array}{l}38 \\
(38.02)\end{array}$ & $\begin{array}{l}2 \\
(1.95)\end{array}$ & $\begin{array}{c}0 \\
(0.03)\end{array}$ & $0.031^{\mathrm{ns}}$ & $\begin{array}{l}31 \\
(30.63)\end{array}$ & $\begin{array}{l}8 \\
(8.75)\end{array}$ & $\begin{array}{l}1 \\
(0.62)\end{array}$ & $0.302^{\mathrm{ns}}$ \\
\hline
\end{tabular}

a A uniform test for the two loci was performed by regrouping genotypes as if they were produced by a pair of alleles, one encoding the most common allele and one encoding all the others (i). ns: not significant $(p>0.05), * 0.05<p<0.02$.

b Expected number, on the assumption of random mating.

Table 8 Genetic variability within populations of Simulium ochraceum from Guatemala. ${ }^{2}$

\begin{tabular}{ccc}
\hline Populations & $P_{\text {poly }}{ }^{*}$ & $\bar{H}^{* *}$ \\
\hline A 1 & 0.286 & 0.113 \\
B 1 & 0.286 & 0.104 \\
B 2 & 0.200 & 0.075 \\
C 1 & 0.286 & 0.101 \\
C 2 & 0.200 & 0.080 \\
D1 & 0.200 & 0.028 \\
Average & 0.243 & 0.084
\end{tabular}

a The locus number used in calculations was 7 for adults and 10 for larvae.

* Proportion of polymorphic loci. The locus was defined as polymorphic, when the frequencies of the commonest allele at a locus were less than 0.99 .

** Average heterozygosity, $\bar{H}=1-\overline{\sum q_{i}{ }^{2}}$.

endemic area of onchocerciasis (Table 8).

\section{Genetic differentiation among populations}

For evaluation of genetic differentiation among the local populations, the mean statistics, $F_{\mathrm{ST}}$ was calculated as shown in Table 9. The value obtained was 0.0166 , but if the D1 population was excluded from the calculation, the value becomes zero (because average sampling variance exceeds measured
Table 9 Genetic differentiation $(\overline{F \text { 'ST }})$ among natural populations estimated from the data of electrophoretic screening of biochemical polymorphism.

\begin{tabular}{|c|c|c|c|}
\hline $\begin{array}{l}\text { Number of } \\
\text { populations }\end{array}$ & $\begin{array}{l}\text { Variable } \\
\text { loci }\end{array}$ & $F \mathrm{ST}^{*}$ & $\overline{F \mathrm{ST}^{*}}$ \\
\hline \multirow[t]{2}{*}{6} & $G P I$ & 0.0176 & \multirow{2}{*}{0.0166} \\
\hline & $P G M$ & $0.0157\}$ & \\
\hline 5 & $G P I$ & $0.0000)$ & \multirow{2}{*}{0.0000} \\
\hline$\left(\begin{array}{c}\text { excluding the } \\
\text { D1 population }\end{array}\right)$ & $P G M$ & $0.0000\}$ & \\
\hline
\end{tabular}

* See text.

Table 10 Gene diversity and gene differentiation among populations of Guatemalan blackflies, S. ochraceum.

\begin{tabular}{cccc}
$\begin{array}{c}\text { Number of } \\
\text { populations }\end{array}$ & $H \mathrm{r}^{*}$ & $H \mathrm{~s}^{*}$ & $G \mathrm{sT}^{*}$ \\
\hline 6 & 0.0989 & 0.0964 & 0.0253 \\
5 & 0.1092 & 0.1079 & 0.0117 \\
$\left(\begin{array}{c}\text { excluding the } \\
\text { D1 population }\end{array}\right)$ & & & \\
\hline
\end{tabular}

* See text.

variance it is necessarily greater than or equal to zero, since $F_{\mathrm{ST}}$ is a measure of the amount of differentiation among the populations), indicating that the D1 population was re- 
Table 11 Matrices of the normalized identity of genes (I) (below the diagonal) and genetic distance (D) (above the diagonal) between each pair of populations of Guatemalan blackflies, Simulium ochraceum.

\begin{tabular}{|c|c|c|c|c|c|c|c|}
\hline & \multirow{2}{*}{$I$} & \multicolumn{6}{|c|}{$D$} \\
\hline & & 1 & 2 & 3 & 4 & 5 & 6 \\
\hline 1. & A 1 & & 0.00050 & 0.00155 & 0.00160 & 0.00152 & 0.00631 \\
\hline 2. & B 1 & 0.99950 & & 0.00120 & 0.00134 & 0.00186 & 0.00532 \\
\hline 3. & B 2 & 0.99846 & 0.99880 & & 0.00378 & 0.00403 & 0.00642 \\
\hline 4. & C. 1 & 0.99842 & 0.99866 & 0.99623 & & 0.00044 & 0.00420 \\
\hline 5. & $\mathrm{C} 2$ & 0.99848 & 0.99814 & 0.99598 & 0.99956 & & 0.00520 \\
\hline 6. & D1 & 0.99371 & 0.99469 & 0.99360 & 0.99581 & 0.99481 & \\
\hline
\end{tabular}

$I=\overline{\Sigma q_{i x} \cdot q_{i y}}\left(\overline{\sum q_{i x}{ }^{2}} \overline{\sum q_{i y}{ }^{2}}\right)^{-1 / 2}, D=-\log \Theta I$, where, $q_{i x}$ and $q_{i y}$ are the allele frequencies of the $i$-th allele at a locus in the populations $x$ and $y$, respectively, and the average is taken over all the loci examined.

markably distinct from other populations. Another estimate of genetic diversity, $G_{\text {ST }}$ is presented in Table 10. The estimate was 0.00253 for comparison of the populations which means that about $25 \%$ of the total genetic diversity is attributable to the genetic difference between the populations.

\section{Genetic distance between populations}

The estimates of genetic distance $(D)$ be-

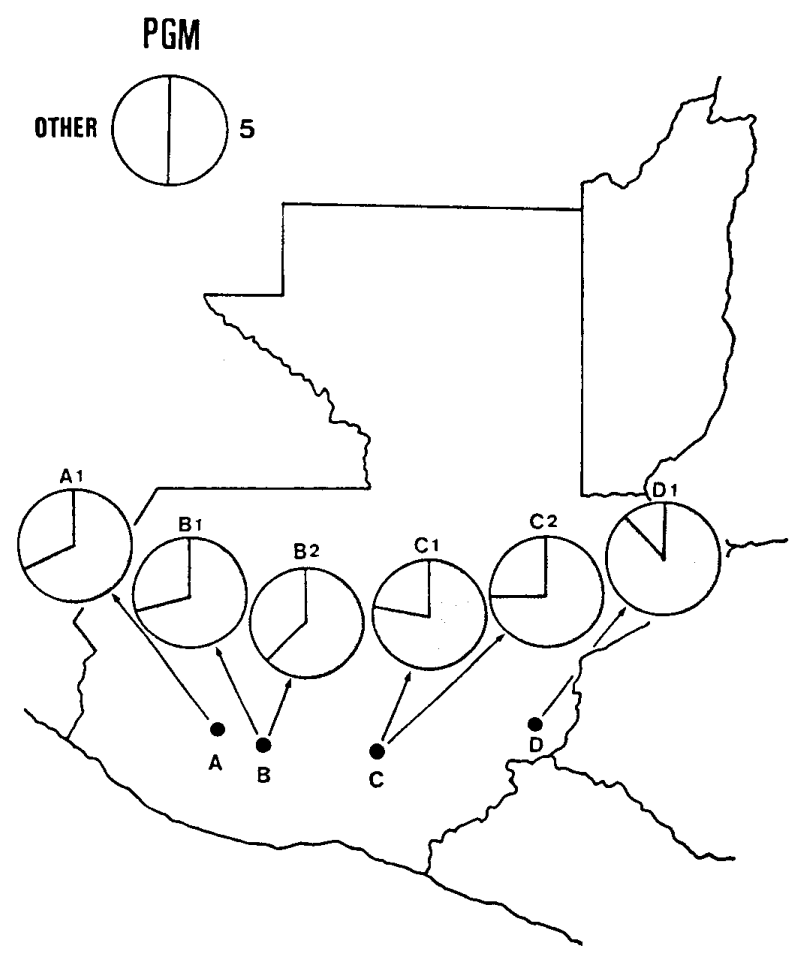

Fig. 3 Geographic distribution of the predominant allele, 5, at $P G M$ locus in six populations of $S$. ochraceum in Guatemala. For abbreviations see Table 1 . tween populations are summarized in Table 11. The lowest estimate of $D$ was 0.00044 between the adult and larval populations (C1 and C2) from the Finca Rincon. The D1 population showed greater distance from all populations examined. However, overall values for each comparison of population pairs can be said to be rather low; even the highest value of $D(0.00642)$ between the $B 1$ and D1 is within the usual range for

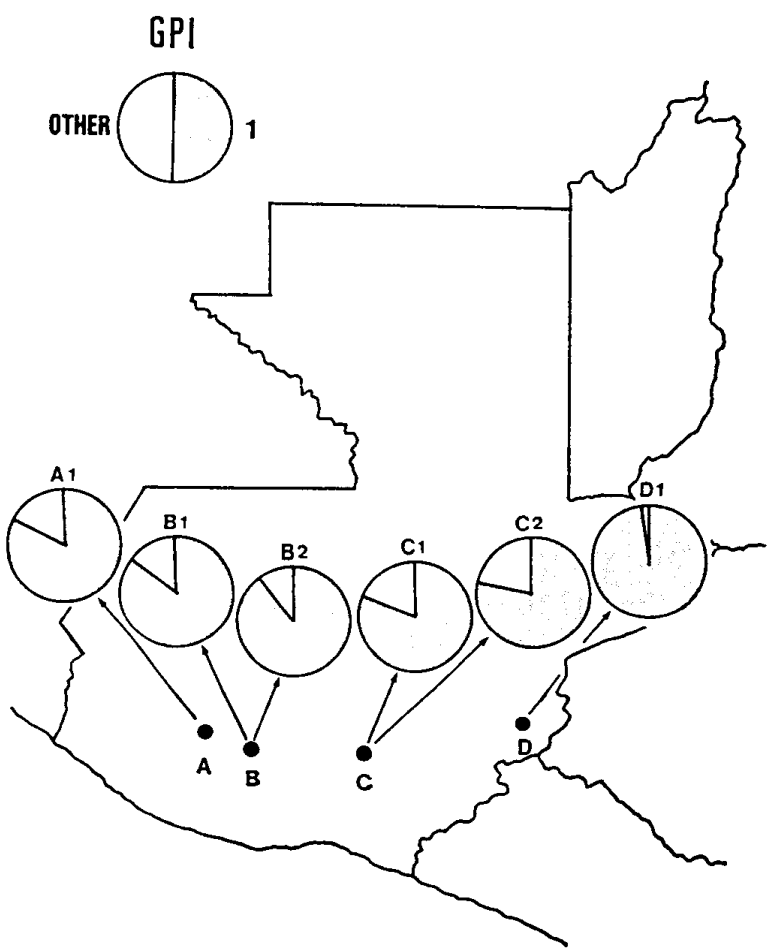

Fig. 4 Geographic distribution of the predominant allele, 1 , at GPI locus in six populations of $S$. ochraceum in Guatemala. For abbreviations see Table 1 . 

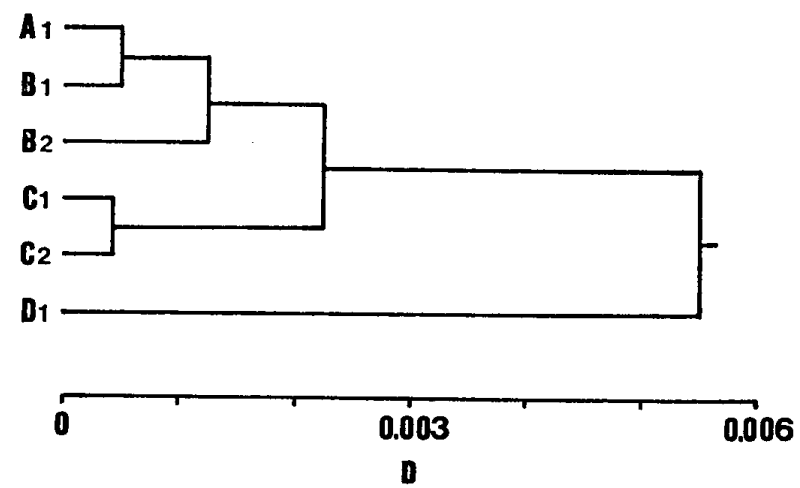

Fig. 5 Dendrogram drawn from the Nei's genetic distances $(D)$ (Table 11) among six populations of $S$. ochraceum using the unweighted pair group method.

conspecific populations (Nei, 1975). From the data in Table 11, a dendrogram was constructed using the unweighted pair-group method as shown in Fig. 5.

\section{Discussion}

All of examined enzymes except IDH and ME showed the same patterns as those of our previous study, and genetic interpretation of each enzyme pattern was done in the same way as before (Agatsuma et al., 1986). A good agreement between expected and observed values of the phenotype frequencies of GPI and PGM supports the genetic interpretation adopted here (Table 7).

In the Finca Rincon, the adults (C1) and larvae (C2) were sampled at almost the same spot, and it was found that there was little difference in the allele frequencies at all the loci examined. Since all the adults sampled were females, this suggested that there seemed to be no difference in allele frequencies between both sexes in this locality. On the other hand, small differences were seen between the adult (B1) and larval (B2) populations when the collection sites were over $5 \mathrm{~km}$ apart, suggesting separate populations.

Clinal pattern was seen at the PGM locus in the frequencies of the allele 5, which was the predominant one in any population examined (Fig. 3). No clinal pattern was evident in any population, however, with regard to the highest allele, 1 , at GPI locus (Fig. 4). The cline of gene freuqencies has been observed in a variety of animal and plant enzymes, and has been suggested as an important evidence of natural selection of molecular variations (e.g. Ayala, 1975). However, the effect of gene dispersal during local differentiation can not be neglected (Nei, 1975). In this respect, the observed clinal pattern in the blackfly enzyme must be studied more intensely to identify any factors of selective force.

The D1 population seemed to be unique because the level of the average heterozygosity $(\bar{H})$ was remarkably low compared with the other populations. Theoretically, a low level of heterogeneity in a population could be maintained if the population was subject to a stabilized selection; that is, a newly arisen variant would always be weeded out from the population. However, there is little evidence so far that selective forces are responsible for the genetic structure of populations. It seems more plausible that random genetic drift may have been involved when a population appears to be rather small and subject to fluctuations, increasing in the rainy season, and decreasing drastically in the dry season. Founder effect could also be one of the major factors in the development of a low level of heterogeneity.

The values of $\overline{F_{\mathrm{ST}}}$ and $G_{\mathrm{ST}}$ in this study were 0.0166 and 0.0253 , but if the D1 population is omitted from the calculation, the values zero and 0.0117 are obtained respectively (Table 9). This clearly means that the D1 population is being much differentiated genetically from the other populations. The genetic distances calculated here also showed that this population is rather far from the other populations phylogenetically, though the values are not so large (Table 11 and Fig. 5).

Uemoto (1984) first recognized significant differences in larval morphology among $S$. ochraceum populations sampled from different localities through Mexico to Guatemala. He stated that there could be at least three sibling species. Afterwards, Hirai (1985) started chromosomal studies using collections from the same localities as those sampled by Uemoto (1984). He also discovered pronounced differences in chromosomal banding patterns, especially on the $\mathrm{Y}$ chromosome, and divided $S$. ochraceum from Mexico and Guatemala into three sibling species, A, B and $\mathrm{C}$, according to the $\mathrm{X}$ and $\mathrm{Y}$ chromo- 
some inversion patterns. In the present study, two of Hirai's three types, A and C, were investigated electrophoretically. Five populations, A1, B1, B2, C1 and C2 of the present study, belong to the A type of Hirai (1985), while the $\mathrm{D} 1$ population belongs to the $\mathrm{C}$ type. According to Hirai's results, type $\mathrm{G}$ is remarkably far from both of the other two types, because it has considerably different chromosome constitution changed by a lot of chromosomal rearrangements. The other two do not possess the inversion on chromosome II which suggests that there is no possibility of interbreeding between them, probably due to the drastic change of chromosomal gene arrangement. Actually, Hirai could not find any intermediate chromosomal pattern between type $\mathrm{C}$ and others in either population (personal communication). These findings are in accord with our results that the D1 population, namely the type $\mathrm{C}$, genetically differs from the other populations all of which are similar and belong to type A. Nevertheless, the present isozyme study did not show marked difference in the genetic distance values between the D1 population and others; the largest one (0.00642) was obtained between the $\mathrm{D} 1$ and $\mathrm{B} 2$ populations, while the smallest $(0.00420)$ was seen between the D1 and C1. Even the largest value is small enough, being within intraspecific range (Avise, 1975). In view of their average genetic distance, the two types, $\mathrm{A}$ and $\mathrm{C}$, cannot be regarded as separate species. However, the standard genetic distance is not always an indicator for showing conventional classification of each taxon (Townson and Meredith, 1979). Indeed, there have been many examples which showed such a discrepancy between biochemical and morphological studies as to classification (see Dobzhansky et al., 1977). As to Simuliidae, cytological studies have revealed in many morphospecies the existence of a sibling species complex, the members of which are reproductively isolated. Enzyme electrophoresis has been applied to the $S$. damnosum complex, for example, and it was found that some enzyme patterns can be used to distinguish some of the sibling species. However, it was also found that not all cytospecies can be distinguished by this method (Townson and Meredith, 1979). Therefore, it is of major importance to recognize that speciation is not necessarily accompanied by extensive enzyme divergence. Furthermore, the genetic distance found between Simulium species need not be the same as those between species in other groups of animals and plants, because the process of speciation occurs in different ways in different organisms.

In any case, although the divergence between types $\mathrm{A}$ and $\mathrm{C}$ might have recently occurred, it should be noted that the present study essentially supported the sibling species theory of $S$. ochraceum by Uemoto (1984) and Hirai (1985).

\section{Acknowledgements}

We wish to thank all the staff members in SNEM of Guatemala for their kind cooperation and encouragement. We are also indebted to Dr. $\mathbf{H}$. Hirumi, ILRAD, Kenya, Dr. J. Raybould, Bristol, England, Professor N. Suzuki and Associate Professor Y. Hashiguchi, Department of Parasitology, Kochi Medical School, Japan, for their helpful criticism and review of this manuscript. We are grateful to Mrs. K. Imamura for her typing of the manuscript.

\section{REFERENCES}

Agatsuma, T., K. Uemoto and J. O. Ochoa A. (1986): Biochemical genetics of blackfly isozymes. I. Isozyme variation among three species, Simulium ochraceum, $S$. metallicum and $S$. horacioi from Guatemala. Jpn. J. Sanit. Zool., 37: $1-9$.

Avise, J. C. (1975): Systematic value of electrophoretic data. Syst. Zool., 23: 465-481.

Ayala, F. J. (1975): Genetic differentiation during the speciation process. Evol. Biol., 8: 1-78.

Dobzhansky, T., F. J. Ayala, G. L. Stebbins and J. W. Valentine (1977): Evolution, 572 pp., W. H. Freeman and Company, San Francisco, California.

Hirai, H. (1985): Cytotaxonomy of Simulium ochraceum Walker (Diptera: Simuliidae), from Guatemala and Mexico. Jpn. J. Sanit. Zool., 36: 163 (in Japanese).

May, B., L. S. Bauer, R. L. Vadas and J. Granett (1977): Biochemical genetic variation in the family Simuliidae: Electrophoretic identification of the human biter in the isomorphic Simulium jenningsi group. Ann. Entomol. Soc. Am., 70: 637-640.

Meredith, S. E. O. (1982): Enzyme identification of Simulium damnosum s.l. caught biting man. Ann. Trop. Med. Parasitol., 76: 375-376. 
Meredith, S. E. O. and H. Townson (1981): Enzymes for species identification in the Simulium damnosum complex from West Africa. Tropenmed. Parasitol., 32: 123-129.

Nei, M. (1972): Genetic distance between populations. Am. Nat., 106: 283-292.

Nei, M. (1975): Molecular Population Genetics and Evolution, 288 pp., North-Holland, Amsterdam and Oxford.

Snyder, T. P. and M. C. Linton (1984): Population structure in blackflies: Allozymic and morphological estimates for Prosimulium mixtum and $P$. fuscum (Diptera: Simuliidae). Evolution, 38: 942-956.

Taylor, A. E. R. and R. Muller (1979): Problems in the Identification of Parasites and Their Vectors 221 pp., Blackwell Scientific Publications, Oxford.

Townson, H. and S. E. Meredith (1979): Identification of the Simuliidae in relation to onchocerciasis. In: Problems in the identification of Parasites and Their Vectors (eds., Taylor, A. E. R. and R. Muller), pp. 145-174, Blackwell Scientific Publications, Oxford.

Uemoto, K. (1984) : Morphological cytotaxonomic and isozyme analysis of the species-complex of blackflies. Jpn. J. Sanit. Zool., 35: 162( in Japanese).

$$
\begin{gathered}
\text { 摘 要 } \\
\text { ブュアイソザイムの遺伝生化学的研究 } \\
\text { II.グァテマラにおけるオンコセル } \\
\text { カ症媒介ブュ Simulium ochraceum } \\
\text { の自然集団における遺伝的変異性 } \\
\text { および遺伝的分化 }
\end{gathered}
$$

グァテマラにおけるオンコセルカ症媒介ブユSimulium ochraceum については, 先に上本 (1984) が 形態分類学的研究を行い, 3 種の sibling species (姉 妹種）に分類しうると提唱した. その後, 平井 (1985)
は染色体分析により同様に 3 種類の sibling species が 存在すると報告した. 本研究では，上本 (1984) およ び平井（1985）が行った地域と同一地域の幼虫および 成虫のアイソザイムパターンを分析し, 彼らの提唱し た sibling species について集団遺伝学的観点から検 討を加えた。調査は非流行地域である Finca La Ruda，低流行地域の Finca Rincon および高度の流行 地域 Finca Brote および Finca Recreo の4 地域で 行い, 幼虫および成虫集団合わせて六つの集団を分析 した. その結果, ます調べた 8 酵素のうち, $\mathrm{AK}$, ALP, HK, IDH, LAP, ME の6 酵素は，すべて集 団内および集団間にまったく変異を示さず，いわゆる monomorphism であることがわかった。しかし残り の 2 酵素 GPI および PGM は変異を示し，どの集 団でも高度に多型的 (polymorphic) であった。 $\chi^{2}$ test を用いてハーディ・ワインベルグの法則からのず れを検定した結果，有意の差がみられず，各集団とも ランダムな交配をしているものと考えられた. 平均人 テロザィゴシティー $\overline{\boldsymbol{H}}$ や多型を示した遺伝子座の割 合 $P$ の値は，それぞれ $0.084,0.234$ であり，他種の 多くの集団で従来より得られた值とほぼ同様の值であ った. 次に集団間の遺伝的分化の程度を調べるため,

$F$ ST および $G$ STを求めた結果，流行地域である Finca La Ruda の集団のみが，他の集団から大きく分化し ていることがわかった. また Nei (1975) の遺伝距離 の值も，この Finca La Ruda 集団が他の集団から遠 く隔たっていることを示した.この遺伝的にかけ離れ た集団は，平井 (1985) が提唱した sibling species “G”に，さらに互いにほとんど差を示さなかった残り の 5 集団は，すべて平井 (1985) の sibling species “A”に相当するものであり，今回のアイソザイム分析 は，染色体分析とほぼ一致することがわかった。ただ genetic distance の値が, 従来得られてきた別種間の 值よりかなり低く，むしろ地方品種間の值に相当して いることが注目された. しかし種分化は必ずしもアイ ソザイムの差異を伴うものではなく，ブユにおける種 分化はむしろ前提として染色体の分化が先行し，後に アイソザイム変異が蓄積するという過程をもつと考え ることもできる．いずれにしても，これら二つの sibling speciesは, 分岐後の経過時間はかなり小さいも のと思われた. 